\title{
動脈硬化用剂の生物物理学的検討 (I)
}

一一脈波速度によるクリノフィブレート(リポクリン®)の効果—

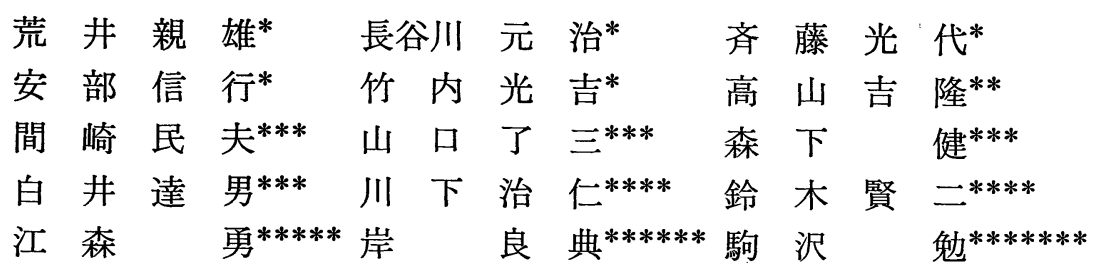

\section{I. はじめに}

われわれは非観血的な動脈硬化評価法である大 動脈脈波速度 (PWV) により各種抗動脈硬化剤の 長期効果を動物実験, 臨床において報告してきた. 今回, PWV 值の推移から血清脂質低下剤クリノ フィブレートの長期投与による器質的動脈硬化病 変の抑制効果について検討し有用な知見を得た.

\section{II. 対象・方法}

対象は動脈硬化性疾患で通院中の年齢47歳から 83 歳, 平均 68.5 歳, 男 28 例, 女 21 例, 計 49 例の抗 動脈硬化剂を投与していない硬化群と年齢48歳か ら83歳, 平均62.9歳, 男24例, 女17例, 計41例の クリノフィブレート投薬群である. 投薬群にはク リノフィブレート $600 \sim 1,200 \mathrm{mg} /$ 日を 3 回に分け 食後投与した. 全例に対し PWV は 3 か月ごと, 血圧は 1 か月ごと, 各種血清脂質と血液化学を 4 か月ごとに実施した。観察期間は硬化群が25か月 から 129 か月, 平均 72.2 か月, 投薬群が 2 か月か

$*$ 東邦大学医学部臨床生理機能学研究室

** 同 ME 研究室

*** 同 第一内科

**** 動脈硬化疫学研究所

****** 社会保険大宮総合病院生理検査科

******* 同科

******** 文部省統計数理研究所
ら 25 か月，平均 12.5 か月である.今回は両群にお ける PWV 值推移について報告し, 他の検查結果 については別の機会に報告する.

Figure 1 はPWV の計測方法を示した. 患者を 背臥位とし頸動脈波, 股動脈派, 心音の同時記録 と第 2 肋間胸骨右縁と股動脈波採取部位の直線距 離の計測を行い以下の式より PWV を求める.

$$
P W V=\left[\frac{D \times 1.3}{t+t_{c}}\right]_{p}
$$

ここで D は第 2 肋間胸骨右縁と股動脈波採取 部位の直線距離, 1.3 は大動脈実長への解剖学的 な補正值, $\mathrm{t}$ は頸動脈波と股動脈波の立ち上がり時 間差, $\mathrm{t}_{\mathrm{c}}$ は心 II 音前成分開始と頸動脈切痕時間差, $\mathbf{P}$ は計測時上腕最小血圧を意味する. PWV は最 小血圧值に依存するため Fig. 2 で示した圧較正 表により最小血圧 $80 \mathrm{mmHg}$ での PWV 值に換算 した. 実際に用いた装置では最小血圧值を入力す ると脈波, 心音の計測点の認識, 圧補正等は自動 化されているため PWV 值はただちに print out される. 同型の装置はすでに MCG-400 (フクダ 電子 ) として実用化されている.

\section{III. 成 績}

Figure 3 は硬化群の 3 例について PWV 推移と 複数測定点より求めた回帰式を示した. 上段は年 齢82歳，男性の例であるが PWV は約 100 か月間 

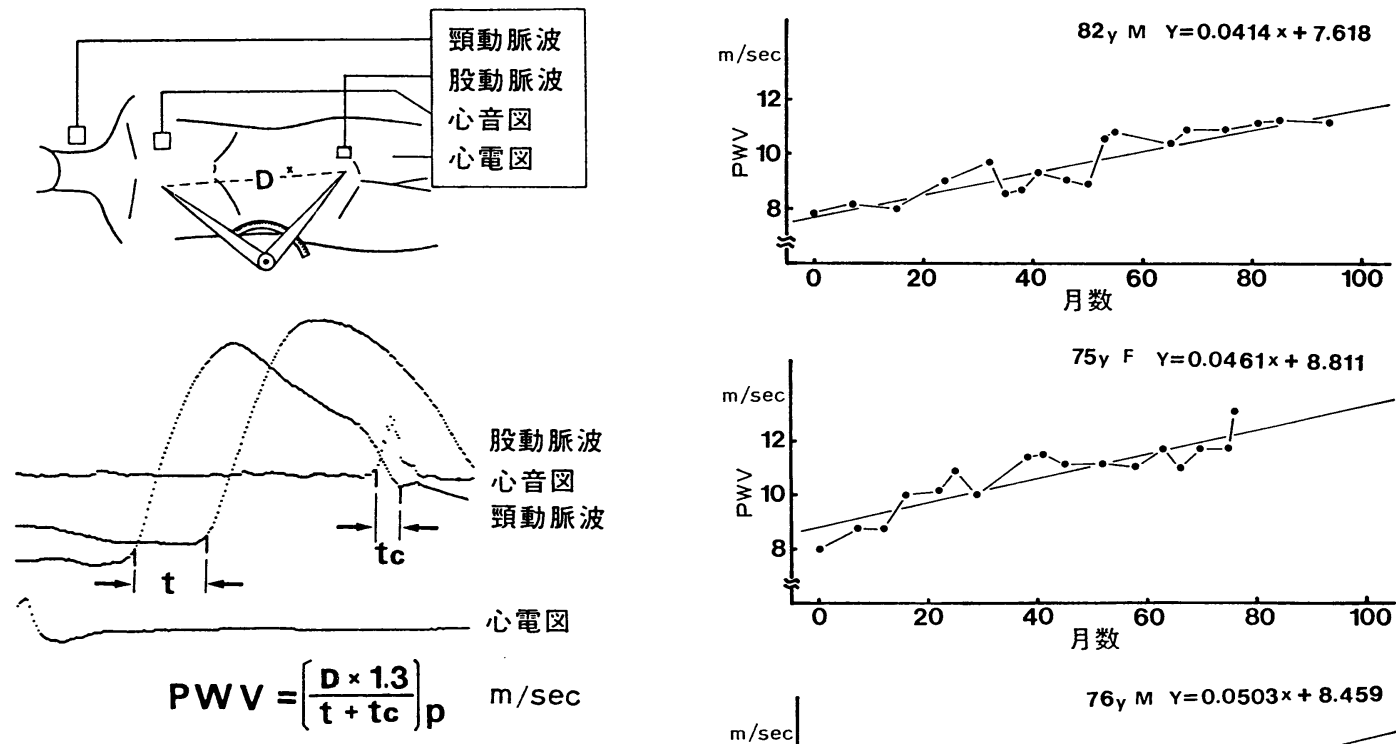

$p:$ 最小血圧

Fig. 1 Method of registration and calculation of aortic pulse wave velocity.
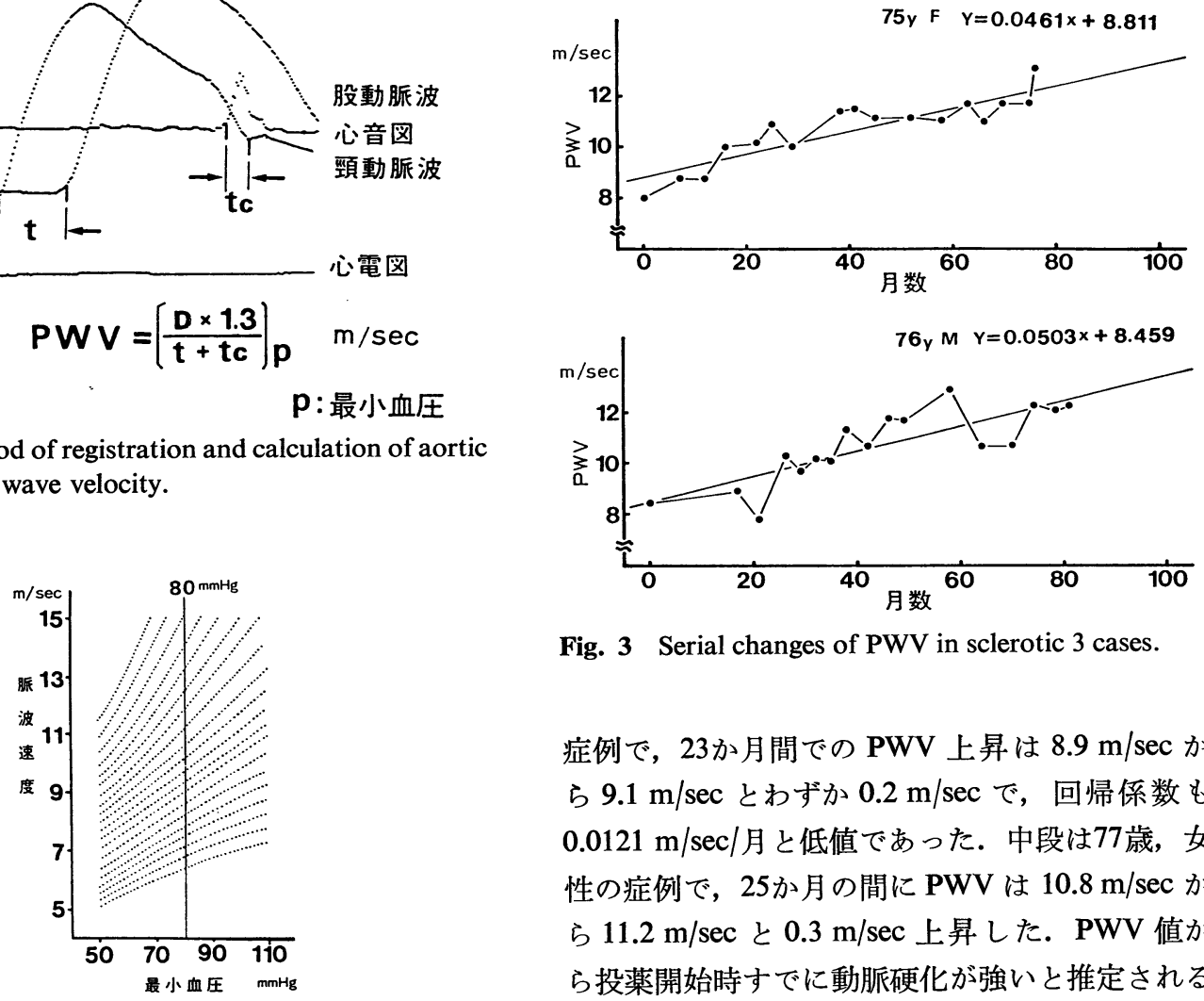

Fig. 3 Serial changes of PWV in sclerotic 3 cases.

症例で, 23か月間での PWV 上昇は $8.9 \mathrm{~m} / \mathrm{sec}$ か ら $9.1 \mathrm{~m} / \mathrm{sec}$ とわずか $0.2 \mathrm{~m} / \mathrm{sec}$ で, 回帰係数も $0.0121 \mathrm{~m} / \mathrm{sec} /$ 月と低值であった. 中段は77歳, 女 性の症例で，25か月の間に PWV は $10.8 \mathrm{~m} / \mathrm{sec}$ か ら $11.2 \mathrm{~m} / \mathrm{sec}$ と $0.3 \mathrm{~m} / \mathrm{sec}$ 上昇した. PWV 值か ら投薬開始時すでに動脈硬化が強いと推定される 症例であるが, 回帰係数は $0.01139 \mathrm{~m} / \mathrm{sec} /$ 月と低 值を示した. 下段の症例は66歳, 女性で PWV は 投与前 $10.6 \mathrm{~m} / \mathrm{sec}$ と高值を示したが, 投薬後26か 月後の PWV 值は $10.4 \mathrm{~m} / \mathrm{sec}$ と $0.2 \mathrm{~m} / \mathrm{sec}$ 低下し, 回帰係数も $-0.00345 \mathrm{~m} / \mathrm{sec} /$ 月と負の值を示した.

Table 1, Fig. 5 は投与前 PWV 值を 0 とし, $\mathrm{PWV}$ 值の変化分 $\Delta \mathrm{PWV}$ の平均を 5 か月ごとに 示した. 破線で示した硬化群の $\Delta \mathrm{PWV}$ は， 5 か 月後 $0.17 \mathrm{~m} / \mathrm{sec}, 10$ か月後 $0.31 \mathrm{~m} / \mathrm{sec}, 15$ か月後 $0.56 \mathrm{~m} / \mathrm{sec}, 20$ か月後 $0.82 \mathrm{~m} / \mathrm{sec}, 25$ か月後 0.90 $\mathrm{m} / \mathrm{sec}$ であったのに対し, 投薬群では， 5 か月後 $0.06 \mathrm{~m} / \mathrm{sec}, 10$ か月後 $0.05 \mathrm{~m} / \mathrm{sec}, 15$ か月後 0.19 $\mathrm{m} / \mathrm{sec}, 20$ か月後 $0.13 \mathrm{~m} / \mathrm{sec}, 25$ 只後 $0.1 \mathrm{~m} / \mathrm{sec}$ 

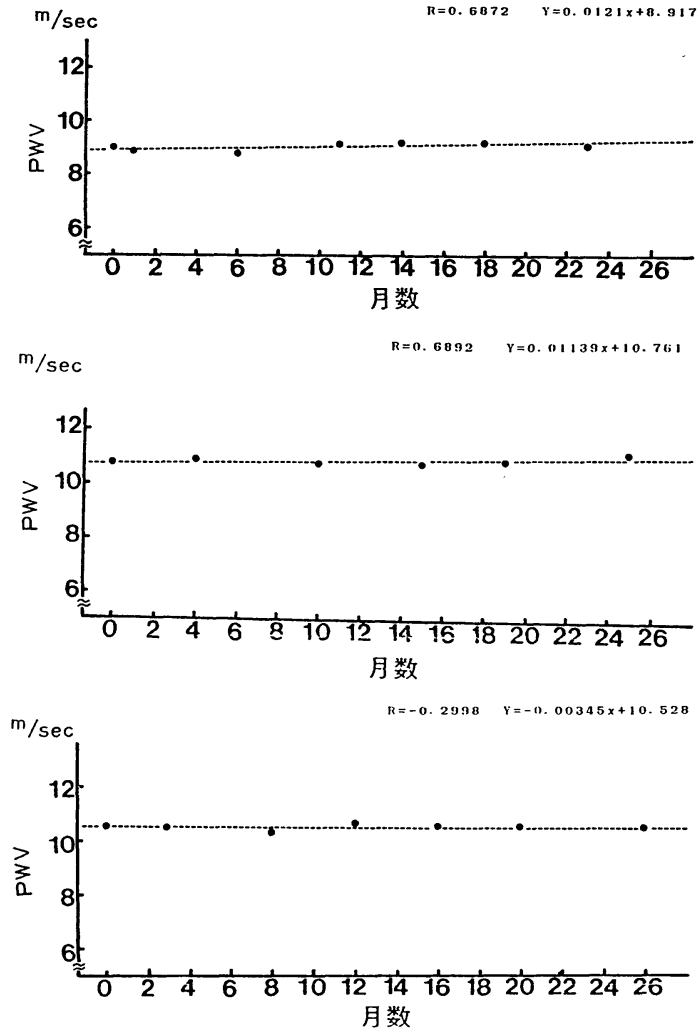

Fig. 4 Serial changes of PWV in administration (clinofibrate) 3 cases.

と $\Delta \mathrm{PWV}$ は低值で推移し, 20, 25 か月後ではお のおの $5 \%, 1 \%$ 以下の危険率で投薬群が低い值 を示した。

\section{IV. 考案}

脈波速度については, 基礎, 臨床, 疫学等の研 究からその有用性を報告してきた ${ }^{1 \sim 6)}$. PWV 值を 実験的動脈硬化家鬼と健常家兔とで対比すると，

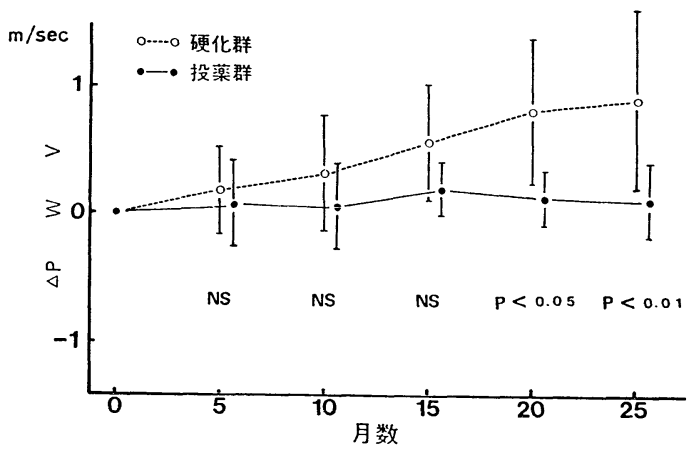

Fig. 5 Serial changes of mean $\triangle \mathrm{PWV}$ in sclerotic and administration (clinofibrate) groups.

6 週以降硬化家鬼群の PWV は上昇し，また組織 学的な検索でも PWV 上昇例では明らかな内中膜 の動脈構築障害を認めることから，動脈硬化の進 展が PWV 值を上昇させていると言える7,8).また ヒトにおいて, 生前の PWV 值と死後大動脈内中 膜組織所見を対比した結果でも動脈硬化病変の程 度と PWV は高い相関が認められている9).

Figures 6, 7,8 では動脈硬化性疾患である心筋 梗塞, 脳梗塞, および動脈硬化合併頻度の高い高 血圧，糖尿病患者の PWV を各年代ごとに対照群 と対比し示したが，いずれも疾患群の PWV が高 值である.

Figure 9 では従来より広く行われている動脈硬 化の検查にPWV を加えた循環器動脈硬化 screening test を施行したのち，発症追跡調查により見 出された動脈硬化性疾患発症者 198 例の PWV を 非発症者 68,486 名のそれと対比した結果である が，各年代とも発症群の PWV が非発症群より高 值を示している. また, Fig. 10 は施行した各検查 の発症に対する寄与度を示したが，PWV は 167

Table 1 Serial changes of mean $\triangle \mathrm{PWV}$ every five months in sclerotic and administration (clinofibrate) groups

\begin{tabular}{|c|c|c|c|c|c|c|c|c|}
\hline & Month & & 0 & 5 & 10 & 15 & 20 & 25 \\
\hline \multirow{4}{*}{$\triangle \mathrm{PWV}$} & Group S & $\mathrm{X}$ & 0 & 0.17 & 0.31 & 0.56 & 0.82 & 0.90 \\
\hline & & $\mathrm{SD}$ & - & 0.33 & 0.46 & 0.47 & 0.59 & 0.71 \\
\hline & Group A & $\mathrm{X}$ & 0 & 0.06 & 0.05 & 0.19 & 0.13 & 0.10 \\
\hline & & SD & - & 0.35 & 0.34 & 0.22 & 0.21 & 0.30 \\
\hline & & & & NS & NS & NS & $\mathrm{p}<0.05$ & $\mathrm{p}<0.01$ \\
\hline
\end{tabular}

S: sclerotic A: administration (clinofibrate) 


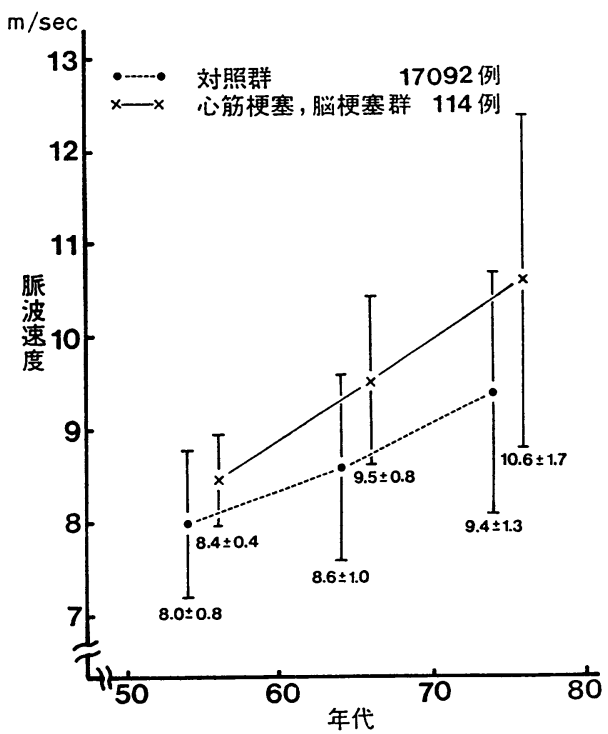

Fig. 6 Mean PWV vs. age in patients with myocardial infarction, cerebral infarction and control groups.

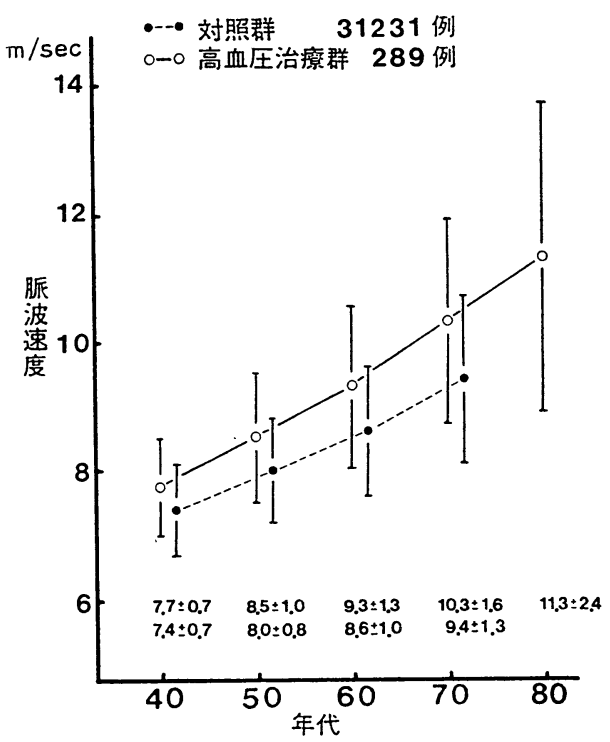

Fig. 7 Mean PWV vs. age in patient with hypertension and control groups.

点と最も高い値を示し, 次いで眼底 124 , 心電図 110，コレステロール 97, 血圧 75 の順であった ${ }^{6)}$.

クリノフィブレートについては血清脂質值の改 善, 動脈壁脂質代謝に対する効果, 胆石形成指数 の減少作用等が明らかにされている10 12). しか

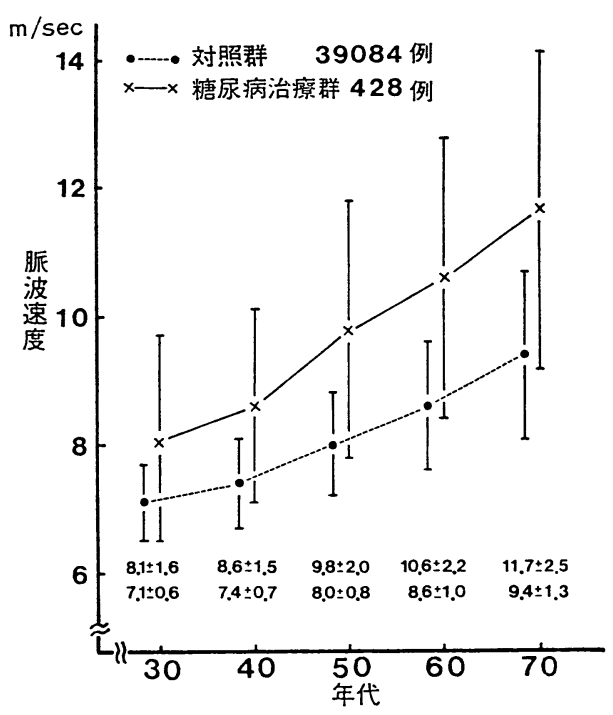

Fig. 8 Mean PWV vs. age in patient with diabetes melitus and control groups.

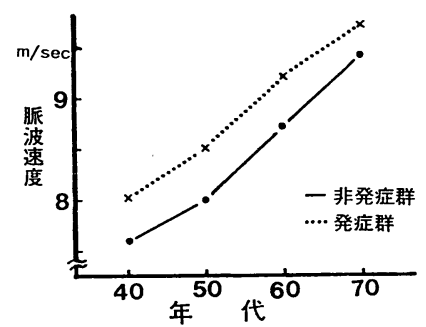

Fig. 9 Mean PWV vs. age in patient with cerebrocardiovascular attack in mass screening test.

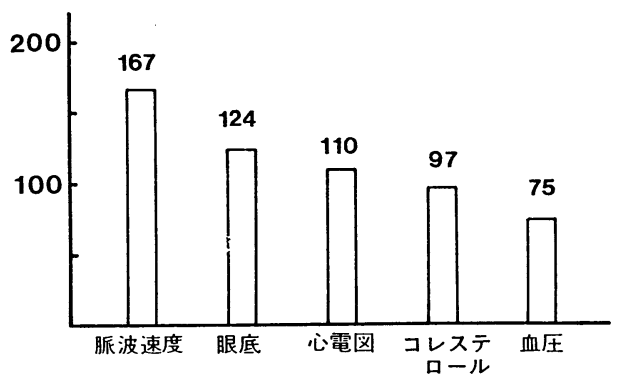

Fig. 10 Contribution score of clinical variables to cerebrocardiovascular attack.

し, 血管物性から動脈硬化を捉え, クリノフィブ レートの長期効果をみた報告はない. 今回, 長期 投与による効果を脈波速度の推移から検討した結 果, 20か月以降投薬群では硬化群に比べ PWV は 


\section{動脈硬化用剂の生物物理学的検討 (I)}

低值となり, 当薬剤に器質的動脈硬化病変の進展 を抑制する効果のあることが示唆された. 今後さ らに長期間にわたり投与し，その持続効果を検討 し, さらに動脈硬化家鬼を用いた実験から動脈構 築障害に対する効果を検討する予定である.

\section{V. 結 語}

1. 生物物理学的な動脈硬化の指標である大動 脈脈波速度によりクリノフィブレートの長期効果 を検討した。

2. PWV 変化 $(\Delta \mathrm{PWV})$ を硬化群 49 例, 投薬群 41 例で比べると, 硬化群では 25 か月後 $0.9 \mathrm{~m} / \mathrm{sec}$ 上昇したのに対し, 投薬群では $0.1 \mathrm{~m} / \mathrm{sec}$ の上昇 に留まった。 20か月以降両群は有意 $(\mathrm{p}<0.05)$ の 差を認めた。

3. クリノフィブレートの長期投与により器質 的動脈硬化病変が抑制されることが示唆された.

\section{文献}

1）長谷川元治：ヒ卜大動脈脈波速度に関する基礎的研 究. 慈大誌, 85: 742-760 (1970).

2) 林 哲郎：動脈硬化症の研究一一生体大動脈脈波速 度による大動脈の定量的測定と臨床応用に関する研 究. 慈大誌, 85: 548-567 (1970).

3）大塚文輝：生体大動脈脈波速度と大動脈壁硬化に関 する研究. 慈大誌, 88: 322-337 (1973).

4) 青木一雄: 生体家鬼大動脈弹性特性に関する研究. 脈管学, 13: 149-166 (1973).

5) 白川幹郎：脈波速度による臟器動脈硬化の推定. 慈 大誌, 89: 62-77 (1974).
6) 森下 健, 平井順一, 長谷川駿, 長谷川元治, 川崎 健, 荒井親雄, 柏倉義弘, 駒沢 勉: 動脈硬化, 高 血圧の疫学的研究 I. 発症疾患と検查項目との対比. 日老医誌, 18: 319-324 (1981).

7) 長谷川元治, 川崎 健, 竹内光吉, 荒井親雄, 柏倉 義弘：家鬼頸動脈ループによる非観血的血圧測定に 関する研究. 脈管学, 22: 225-228 (1982).

8）長谷川元治, 荒井親雄, 斎藤光代, 竹内光吉, 安部 信行, 川崎 健, 高山吉隆, 駒沢 勉: 家鬼硬化動 脈の機能と構筑障害. 動脈硬化, 11: 1019-1029 (1983).

9) 荒井親雄, 安部信行, 竹内光吉, 斎藤光代, 長谷川 元治, 高山吉隆, 間崎民夫, 森下 健, 白井達男, 川下治仁，鈴木賢二：生前大動脈脈波速度值と死後 組織対比一アテローム, 石灰化, 内・中膜エラス チン, コラーゲンとの関連について—. 動脈硬化, 投稿中.

10) 奥野巍一: S-8527 (リポクリン®) $600 \mathrm{mg} /$ 日投与の 効果. Geriatric Medicine (老年医学), 16:1169-1176 (1978).

11）古賀俊逸, 荘野哲朗, 井上雅公, 他：高脂血症患者 の血漿脂質およびリポ蛋白に対する Clinofibrate 投 与の臨床成績. 動脈硬化, 12: 323-333 (1984).

12）白井厚治, 佐々木憲裕, 石川 洋, 西出敏雄, 藤山 葉子, 斉藤 康, 熊谷 朗, 他：動脈硬化ラット血 管壁脂質代謝に及ぼすクリノフィブレートの影響. 動脈硬化，11: 611-616 (1983).

13）武内 望, 茎田仁志, 梶山梧朗, 他：高脂質血症な らびに胆石症患者の胆汁 lithogenecity に対するク リノフィブレートの影響について. 動脈硬化, 9: 909-916 (1982).

14）堀内 至, 日野文明, 西村正二, 中川 隆, 平川信 江, 高野耕基, 中川公博, 梶山梧朗: Clinofibrate および Cholestyramine の胆汁脂質に及ぼす効果. 動脈硬化，11: 603-609 (1983). 


\title{
Summary
}

\section{Biophysical Study of Antiarteriosclerotic Agent (I) -Effect of Clinofibrate Examined by Aortic Pulse Wave Velocity-}

\author{
Chikao Arai*1, Motoharu HasegawA*1, Mitsuyo SaIto*1, Nobuyuki AbE*1, \\ Kokichi TaKeUchi*1, Yoshitaka TaKaYAma*2, Tamio MaSAKI*3, Ryozo YAMAguchi*3, \\ Ken Morishita*3, Tatsuo ShIRAI*3, Haruhito KaWASHIMo*4, Kenji SuzUKI*4, \\ Isamu EMORI*5, Yoshinori KISHI*6 and Tsutomu KomaZAWA*7 \\ ${ }^{* 1}$ Department of Clinical Functional Physiology, Faculty of Medicine, Toho University \\ *2Department of Medical Engineering, Faculty of Medicine, Toho University \\ ${ }^{* 3}$ The First Department of Internal Medicine, Faculty of Medicine, Toho University \\ ${ }^{*}$ Eppidemic Institute of Arteriosclerosis ${ }^{* 5}$ Central Clinical Laboratory, Omiya Insurance Hospital \\ ${ }^{* 6}$ Department of Internal Medicine, Omiya Insurance Hospital ${ }^{* 7}$ Institute of Statistical and Mathematics
}

Effect of clinofibrate, a serum lipid reducing agent, upon prolonged administration was studied referring to rise and fall of aortic pulse wave velocity (PWV) that is one of the nonivasive evaluations of arteriosclerosis.

A total of 49 patients including 28 males and 21 females with arteriosclerotic diseases without administration of antiarteriosclerotic agent, their age ranging from 47 to 83 years, 68.5 years on an average, were used as the sclerotic group (S group), while a total of 41 patients including 24 males and females under administration of clinofibrate (Lipoclin ${ }^{\circledR}$ ) at $600-1,200 \mathrm{mg} /$ day, their age ranging from 48 to 83 years, 62.9 years on an average, were used as the administration group (A group).

PWV was applied to all of the patients every 3 months, blood pressure was measured once a month, and blood chemical assay of serum lipid, etc., was carried every 4 months. The observation period ranged from 25 to 129 months (72.2 months on an average) for the $\mathrm{S}$ group and from 2 to 25 months (12.5 months on an average) for the A group. PWV was measured by simultaneous tracing of carotid pulse, femoral pulse and heart sound as well as distance in a straight line from the right sternal border connected with the second costa to the position whereat femoral pulse was traced, using the following formula:

$P W V=\left[D \times 1.3 / t+t_{e}\right]_{p}$

wherein:

D: Distance in a straight line from the right sternal border connected with the second costa,

1.3: Anatomical smoothing value to the true length of aorta,

t: Starting time difference between carotid and femoral pulse tracings,

$t_{c}$ : Starting time difference between aortic second sound and carotic notch, and

p: Minimum brachial pressure upon measurement.

As PWV depends on the minimum blood pressure, correct it to a PWV at minimum blood pressure of $80 \mathrm{mmHg}$ using a pressure calibration to have individuals comparable.

When changes of PWV ( $\triangle \mathrm{PWV}$ ) on an average of both groups are compared every 5 months, it was $0.17 \mathrm{~m} / \mathrm{sec}$ by 5 months, $0.31 \mathrm{~m} / \mathrm{sec}$ by 10 months, $0.56 \mathrm{~m} / \mathrm{sec}$ by 15 months, $0.82 \mathrm{~m} / \mathrm{sec}$ by 20 months and $0.90 \mathrm{~m} / \mathrm{sec}$ by 25 months respectively in the $\mathrm{S}$ group, while in the A group it was $0.06 \mathrm{~m} / \mathrm{sec}$ by 5 months, $0.05 \mathrm{~m} / \mathrm{sec}$ by 10 months, $0.19 \mathrm{~m} / \mathrm{sec}$ by 15 months, $0.13 \mathrm{~m} / \mathrm{sec}$ by 20 months and 0.1 $\mathrm{m} / \mathrm{sec}$ by 25 months respectively. PWV varied within the low level, and after 20 and 25 months the A group showed the lower value at $5 \%$ and $1 \%$ levels of significance respectively.

It was suggested that upon prolonged administration of clinofibrate, organic arteriosclerotic lesion is inhibited.

Key words: Clinofibrate, Aortic pulse wave velocity, Arteriosclerosis. 